\title{
THE SURVIVAL OF SCLEROTIA OF SCLEROTINIA TRIFOLIORUM ERIKSS. ON THE SOIL AND THE OCCURRENCE OF CLOVER ROT IN VARIOUS YEARS
}

\author{
Anna-Marja Halkilahti \\ Department of Plant Pathology University of Helsinki
}

Received May 12, 1962

It is generally considered at the present time that Sclerotinia trifoliorum survives during the summertime mainly in the form of sclerotia. These sclerotia can give rise to either mycelia or apothecia. It has been established that both the mycelia $(7,17)$ and the ascospores $(3,7,10,11,15,19,21,23)$ can infect clover. The possibility has also been pointed out that infection can take place by means of mycelia or spores which were present in the seed lot $(3,15,16)$. The sclerotia have a durable outer covering consisting of 3-4 layers of cells which protects them from unfavourable external influences (9). Thus sclerotia are able to live for many years, although in general they are often rapidly destroyed in the soil. ERIKSson (5) assumed that sclerotia in the soil remain viable during only one summer. At times sclerotia are completely destroyed within about two months (24), while often a large share of them survive in the soil for many years $(3,9,19)$ and have been known to live for over seven years (16). - The present investigation deals with the survival of sclerotia of Sclerotinia trifoliorum on the soil, their ability to infect clover, and the occurrence of clover rot at the Viik Experimental Farm of the University of Helsinki during the years $1954-1961$. In addition, the appearance of apothecia in various years has also been studied.

The ability of the mycelia produced by sclerotia of S. $t$ rifol $i$ or $u$ m to infect clover

Various strains of clover rot fungi differ in their ability to produce apothecia $(14,17)$; some strains do not produce them at all (2). The formation of apothecia even in favourable temperature and moisture conditions is unpredictable $(2,8,9,21)$. 
Thus attention has been directed toward the formation of mycelia by the sclerotia which subsequently infect clover. FRANDSEN (7) is of the opinion that direct infection via mycelia is most common.

In the present trials clover was infected with sclerotia both in the laboratory and on the field. - In the laboratory trials some of the sclerotia were untreated, some of them were disinfected by dipping them in chloroform and keeping them for one hour in closed Petri dishes; other sclerotia were cleaved. Containers $19 \mathrm{~cm}$ in diameter and $12 \mathrm{~cm}$ in height were filled with earth and sown with clover. When the seedlings were about one month old, sclerotia were placed near them, both in the. soil at a depth of $2 \mathrm{~cm}$ and also on the surface of the soil. A glass cover was then placed over the seedlings.

Table 1. The ability of the mycelia produced by sclerotia of $S$. trifoliorum to infect clover

\begin{tabular}{ccc}
\hline Treatment of sclerotia & \multicolumn{2}{c}{ Number of sclerotia } \\
& Total & Infecting clover \\
\hline
\end{tabular}

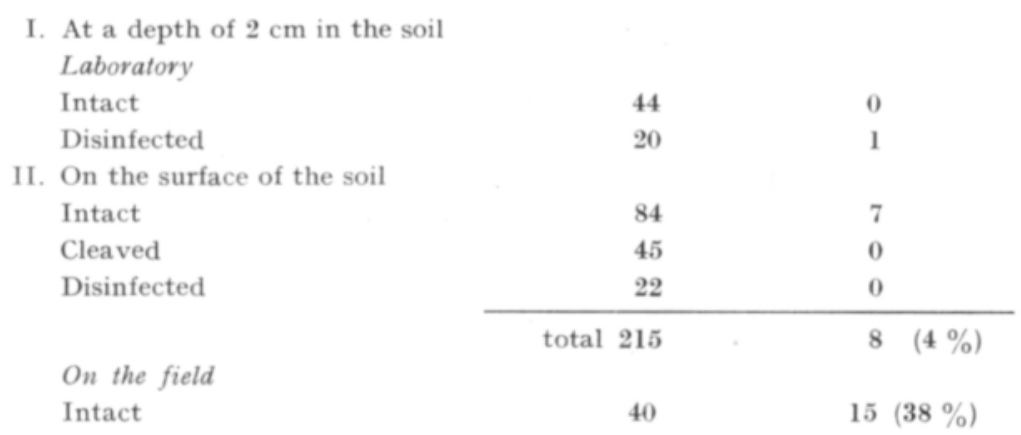

Of all the sclerotia used in this laboratory trial about $4 \%$ infected clover (Table 1). Only uncleaved sclerotia caused infection; the disinfection had hardly any effect on the infection of clover plants. The sclerotia which infected clover disintegrated, and likewise a large proportion of the other sclerotia $(86 \%)$ also disintegrated. Fungi were found in these, among others Fusarium species. After $3 \frac{1}{2}$ months only $10 \%$ of the sclerotia were still intact and viable.

In a field trial carried out in the autumn $1954,38 \%$ of the sclerotia infected adjacent clover plants (Table 1). At three places in the trial plot $\left(4 \mathrm{~m}^{2}\right)$ spontaneous infection took place.

The survival of sclerotia of S. trifoli or $u$ m on the soil during the years $1954-1961$

Trial conditions and methods. These studies were carried out by transferring in May of each year 500 sclerotia (1 000 in 1954) to the field, where they were allowed to remain until they were completely destroyed. The sclerotia were placed on the 
Table 2. The effect of weather conditions on the survival of sclerotia of $S$. trifoliorum on the soil. Number of sclerotia each year 500 (1 000 in 1954). Each trial begun in May; survival \% in November calculated from the number of sclerotia in the previous November (or at the beginning of the trial). $-=$ trial ended.

\begin{tabular}{|c|c|c|c|c|c|c|c|c|c|}
\hline \multirow{2}{*}{$\begin{array}{l}\text { Year trial } \\
\text { begun }\end{array}$} & \multicolumn{9}{|c|}{ Survival \% } \\
\hline & 1954 & 1955 & 1956 & 1957 & 1958 & 1959 & 1960 & 1961 & \\
\hline 1954 & 5 & - & & & & & & & \\
\hline 1955 & & 98 & 50 & 2 & - & & & & \\
\hline 1956 & & & 89 & 60 & 60 & 28 & 5 & - & \\
\hline 1957 & & & & 62 & 87 & 67 & 14 & 4 & \\
\hline 1958 & & & & & 78 & 76 & 5 & 100 & \\
\hline 1959 & & & & & & 59 & 43 & 64 & \\
\hline 1960 & & & & & & & 1 & - & \\
\hline 1961 & & & & & & & & 55 & \\
\hline June-Sept.: & & & & & & & & & Average \\
\hline mean temp $\left({ }^{\circ} \mathrm{C}\right)$ & 14.4 & 15.8 & 13.4 & 14.0 & 13.5 & 15.1 & 15.0 & 14.5 & 14.5 \\
\hline rainfall $(\mathrm{mm})$ & 363 & 135 & 318 & 349 & 192 & 145 & 416 & 290 & 276 \\
\hline
\end{tabular}

surface of soil in wooden boxes (about $40 \times 30 \times 10 \mathrm{~cm}$ in size) which were partially buried in the ground in a shady place. During the summer weeds grew in the boxes. In order to determine the cause of the destruction of the sclerotia, they were inspected at regular intervals during the summer. At the same time observations were made on the appearance of apothecia. In November before the arrival of snow, counts were made of the numbers of sclerotia remaining. Some sclerotia had disappeared completely; soft and otherwise dead sclerotia were removed, and those still living were left on the surface of the soil in the boxes.

The sclerotia used in these trials had been cultured in the previous winter on a Henneberg agar culture medium (dist. $\mathrm{H}_{2} \mathrm{O} 100 \mathrm{ml}$, glucose $10 \mathrm{~g}, \mathrm{CaCl} 0.01 \mathrm{~g}$, $\mathrm{MgSO}_{4} 0.05 \mathrm{~g}, \mathrm{KNO}_{3} 0.2 \mathrm{~g}, \mathrm{NH}_{4} \mathrm{H}_{2} \mathrm{PO}_{4} 0.2 \mathrm{~g}$, peptone $1 \mathrm{~g}$ ). In the years $1954-1960$ a single-spore strain of $S$. trifoliorum was used which had been isolated from apo-

Table 3. The survival of different-aged sclerotia of $S$. trifoliorum on the soil. Number of sclerotia each year 500 (1 000 in 1954). Each trial was begun in May; survival \% in November calculated from the number of sclerotia in the previous November (or at the beginning of the trial). $-=$ trial ended.

\begin{tabular}{|c|c|c|c|c|c|c|c|c|c|}
\hline \multirow{2}{*}{$\begin{array}{l}\text { Years trial } \\
\text { continued }\end{array}$} & \multicolumn{9}{|c|}{ Survival \% } \\
\hline & 1954 & $\begin{array}{l}1955- \\
1957\end{array}$ & $\begin{array}{l}1956- \\
1960\end{array}$ & $\begin{array}{l}1957- \\
1961\end{array}$ & $\begin{array}{l}1958- \\
1961\end{array}$ & $\begin{array}{l}1959- \\
1961\end{array}$ & 1960 & 1961 & Average \\
\hline $1 / 2$ & 5 & 98 & 89 & 62 & 78 & 59 & 1 & 55 & 50 \\
\hline $11 / 2$ & - & 50 & 60 & 87 & 76 & 43 & - & & 62 \\
\hline $21 / 2$ & & 2 & 60 & 67 & 5 & 64 & & & 36 \\
\hline $31 / 2$ & & - & 28 & 14 & 100 & & & & 24 \\
\hline $41 / 2$ & & & 5 & 4 & & & & & 5 \\
\hline
\end{tabular}


thecia at Viik. When this strain finally degenerated and produced only very few sclerotia, a new isolate for the 1961 trials was made in the autumn 1960 from mycelia growing in red clover.

The results from these trials have been statistically analyzed according to the method of MUdRA (13).

Results. The survival of sclerotia of S. trifoliorum on the surface of the soil under outdoor conditions varied considerably in the different years. (Table 2). Some of the sclerotia were destroyed already in the first summer, while some lived as long as over $4 \frac{1}{2}$ years. Their survival clearly decreased with an increase in their age (Table 3).

Apothecia were produced during the period August-September mainly in those sclerotia which had overwintered once or twice. They were formed even in some sclerotia which had overwintered four times. In the trials which were begun in May of the years 1958 and 1961, formation of apothecia took place in the autumn of these same years. In 1958 they were most numerous; in this year about half of the sclerotia which had overwintered once and twice produced apothecia. In general, however, formation of apothecia during the years of these trials was relatively scanty.

Parasitic fungi and bacteria were found to cause the destruction of the sclerotia. In the summer 1960 unusually many fungi (Acrostalagmus, Mucor, Trichoderma etc.) were found in the sclerotia which had been placed on the ground in May of this year, and as a result they were almost completely destroyed. In some cases snails were found to eat the sclerotia.

The survival of sclerotia depended to a large extent upon the weather conditions during the summer months (Table 2). In the summers 1955, 1958 and 1959 the weather was relatively dry, and thus the sclerotia survived well. In 1955, for example, nearly all of the sclerotia which were transferred to the field in this year survived. In dry years the temperature appeared to have no effect on the survival of sclerotia. On the other hand, during rainy summers their survival was clearly related to the temperature. The higher the temperature, the more poorly the sclerotia survived. The largest number of sclerotia were destroyed in the summer of 1960 when the rainfall was the greatest and the temperature higher than in the other rainy summers. In this year there was almost complete destruction of the sclerotia which were put

Table 4. The effect of precipitation and mean temperature (June-Sept.) on the survival of differentaged sclerotia of $S$. trifoliorum (according to multiple correlation calculations).

\begin{tabular}{|c|c|c|c|}
\hline \multirow[b]{2}{*}{ Years sclerotia in the soil } & \multirow{2}{*}{$\begin{array}{c}\text { No. of } \\
\text { trial } \\
\text { years }\end{array}$} & \multicolumn{2}{|c|}{ Regression coefficients } \\
\hline & & $\begin{array}{c}\mathrm{b}_{1} \\
\text { Mean temp. }\left({ }^{\circ} \mathrm{C}\right)\end{array}$ & $\begin{array}{c}\mathrm{b}_{2} \\
\text { Precipitation }(\mathrm{mm})\end{array}$ \\
\hline $1 / 2$ (all years) & 8 & -17.4 & $-0.28^{*}$ \\
\hline $1 / 2$ (rainy years) & 5 & $-55.4^{*}$ & -0.35 \\
\hline $11 / 2$ & 5 & -3.3 & -0.14 \\
\hline $21 / 2$ & 5 & +3.4 & -0.26 \\
\hline
\end{tabular}


on the field in May. In 1956 the summer temperature was low, and as a result the sclerotia survived better than in the other wet summers.

The correlation between weather conditions and survival of the sclerotia was statistically significant only in the case of the first summer after the sclerotia were transferred to the field (Table 4). The correlation between survival of the sclerotia and their age was negative $\left(\mathrm{r}=-0.91 ; \mathrm{b}=-12.8^{*}\right)$.

\section{Occurrence of clover rot in the years $1954-1961$}

Clover rot observations were made annually on a red clover field one-hectare in size. The site of this field changed from year to year on a uniform 10-hectare area. In addition, observations were also made on clover field trials which were located

Table 5. The occurrence of clover rot and apothecia of S. trifoliorum and the autumn weather conditions at Viik in the years $1954-1961$

\begin{tabular}{|c|c|c|c|c|c|c|c|c|c|c|c|c|}
\hline \multirow[b]{2}{*}{ Year } & \multirow{2}{*}{$\begin{array}{c}\text { Occurrence } \\
\text { of apo- } \\
\text { thecia } 0-3 \\
3=\text { abun- } \\
\text { dant }\end{array} \mid$} & \multicolumn{2}{|c|}{$\begin{array}{l}\text { Occurrence of } \\
\text { clover rot }\end{array}$} & \multicolumn{4}{|c|}{ Mean temperature ${ }^{\circ} \mathrm{C}$} & \multicolumn{4}{|c|}{ Precipitation mm } & \multirow{2}{*}{$\begin{array}{l}\text { Date of } \\
\text { lasting } \\
\text { snow } \\
\text { cover }\end{array}$} \\
\hline & & $\begin{array}{c}\text { Abundance } \\
* * * * * \\
\text { maximum }\end{array}$ & $\begin{array}{c}\text { Date of } \\
\text { first } \\
\text { appear- } \\
\text { ance }\end{array}$ & Sept. & Oct. & Nov. & $\begin{array}{c}\text { Aver- } \\
\text { age }\end{array}$ & Sept. & Oct. & Nov. & Total & \\
\hline 1954 & 1 & $* * *$ & 27.9 & 11.0 & 5.3 & 0.9 & 5.7 & 123 & 61 & 76 & 260 & 23.12 \\
\hline 1955 & 3 & $(*)$ & 11.11 & 13.4 & 5.8 & -0.5 & 6.2 & 61 & 62 & 54 & 177 & 21.11 \\
\hline 1956 & * & $* *$ & 7.10 & 8.3 & 4.8 & -4.2 & 3.0 & 36 & 47 & 50 & 132 & $27.1^{1}$ \\
\hline 1957 & 1 & $* *(*)$ & 7.10 & 9.4 & 5.7 & 1.2 & 5.4 & 102 & 93 & 25 & 221 & 30.12 \\
\hline 1958 & 1 & $* *$ & 13.10 & 9.7 & 6.2 & 3.6 & 6.5 & 32 & 48 & 51 & 131 & 8.12 \\
\hline 1959 & 0 & - & - & 8.4 & 4.0 & 1.9 & 4.8 & 7 & 38 & 47 & 89 & 7.12 \\
\hline 1960 & 0 & $* * * * *$ & 10.10 & 9.9 & 3.3 & 0 & 4.4 & 70 & 29 & 109 & 206 & $2.1^{2}$ \\
\hline 1961 & 0 & $*$ & 25.9 & 9.4 & 8.3 & 2.1 & 6.6 & 29 & 35 & 66 & 130 & 28.11 \\
\hline
\end{tabular}

near the same field. Table 5 shows results of the clover rot observations made during the various years. The extent of clover rot is indicated by the number of crosses, and the mark "- shows that there was no evidence of the disease at all. The appearance of apothecia was evaluated using a scale of $0-3$, in which 3 indicates abundant apothecia.

According to Table 5, it can be seen that clover rot occurred most severely in autumns which had a large rainfall. The greatest damage occurred in 1960, when the destruction to the clover field was so great that it had to be plowed in the following spring. Temperature was not found to have a clear influence on the occurrence of clover rot. On the other hand, large damage by clover rot was generally found in those autumns when a lasting snow cover came late. Apothecia were most abundant 
in 1955; in this year the month of September was warmer than normal. In general, only few apothecia were observed and in some years they were not found at all. Clover rot, however, occurred in all years with the exception of 1959.

\section{Discussion}

According to Nicolaisen et al. (14) the formation of apothecia of S. trifoliorum is primarily dependent upon weather conditions. In Finland they are formed especially in September (17); in more southern countries they appear later, sometimes as late as during the winter $(3,7,10)$. Formation of apothecia occurs under conditions of abundant moisture and at temperatures of between +5 and $+20^{\circ} \mathrm{C}(2)$, with the optimum being $+14^{\circ} \mathrm{C}(8)$. During the period $1954-1961$ the maximum number of apothecia at Viik was found in the autumn 1955. In September of this year the temperature was higher than normal and close to the optimum for formation of apothecia. Clover rot also occurred on the fields in the autumns of 1960 and 1961, even though no apothecia were found in these years (Table 5). In this case infection was evidently due mainly to mycelia. Direct infection by means of mycelia from the sclerotia was confirmed in trials (Table 1; cf. also 7 and 17).

Sclerotia were most readily destroyed in wet and warm summers (Table 2). They are found to be infected by several species of parasitic fungi and bacteria (cf. 4, 12, $20,22)$. In addition, they are eaten by worms, centipedes (5), insect larvae $(5,24)$ and by snails; the latter were found also in the present investigations. In our experiments the main cause of the destruction of sclerotia was evidently parasitic fungi and bacteria. They occur most abundantly in rainy summers (18) and infect sclerotia more rapidly under conditions of high temperature and moisture content $(6,12)$. According to Hino (9), the outer covering of sclerotia becomes soft in moist conditions and thus becomes susceptible to attack by parasitic fungi and bacteria. Excessive moisture is also necessary for the formation of apothecia. The extent to which the germination of sclerotia resulted in their decay was not further investigated in these studies.

The survival of sclerotia was found to decrease in relation to their increasing age (Table 3).

The trials carried out on the survival of sclerotia indicate that there are parasites of the sclerotia of clover rot fungus living in the soil and that their occurrence is greatly influenced by weather conditions. In addition, it is known that there are different strains of $S$. trifoliorum which differ in their morphological and physiological characteristics $(2,7,14,15,16,17,21)$. It is thus likely that there are differences in the disease resistance between various strains. This has been found in the case of $S$. sclerotiorum (12). In addition, the external conditions under which the sclerotia were formed has an effect on their resistance to disease infection (12). According to Hino (9), the outer covering of the sclerotia is thicker when they have been formed outdoors under natural conditions than on culture medium in Petri dishes.

Neither the abundance of apothecia of S. trifoliorum (Table 5) nor the extent of destruction of sclerotia (Table 2) were found to have a clear effect on the occurrence 
of clover rot on fields (Table 5). Clover rot appears to be dependent principally upon the weather conditions in the autumn, especially upon the rainfall (Table 5). It has been generally found that wet and warm autumn weather conditions hasten the spread of clover rot $(1,7,16)$.

\section{Conclusions}

The survival of sclerotia of Sclerotinia trifoliorum placed on the surface of the ground in the spring varied considerably; some were destroyed already in the first summer, while others survived as long as about $4 \frac{1}{2}$ years.

The survival of sclerotia was clearly dependent upon weather conditions during the period June-September. In dry years they survived well. In wet summers their survival was better as the temperature was lower. In years when the rainfall was abundant and the temperature high, the destruction of sclerotia was very great.

As the age of the sclerotia increased, their survival correspondingly decreased.

Sclerotia were destroyed by, among other things, parasitic bacteria and fungi as well as snails.

The extent of clover rot on fields was primarily dependent upon weather conditions in the autumn, especially upon the precipitation and the length of the autumn.

\section{KIRJALLISUUSLUETTELO}

(1) Bingefors, S. 1951. Sambandet mellan väderleksförhållandena och omfattningen av klöverrötangreppen vid Ultuna under åren 1930-1950. Sver. Utsädesför. Tidskr. 61, 3: 100-107.

(2) Björling, K. 1951. Uber die Entwicklungsgeschichte, Variabilität und Pathogenität von Sclerotinia trifoliorum Erikss. Phytopath. Z. 18, 2: 129-156.

(3) Coleman, L. C. 1907. Uber Sclerotinia trifoliorum Eriksson, einen Erreger von Kleekrebs. Arb. Kaiserl. Biol. Anst. 5: 469-488.

(4) EKstrand, H. 1938. Några ekonomiskt viktiga sjukdomar på höstsäd och vallväxter. Stat. Växtskyddsanst. Medd. 25.

(5) ERIKsson, J. 1880. Om Klöverrötan med särskilt afseende på dess uppträdande $\mathrm{i}$ vårt land åren 1878-1879. Kungl. Landbr. Akad. Handl. o. Tidskr. 1.

(6) Erviö, L-R., Нацкilahti, A-M. \& Pohjakallio, O. On Surviving in the Soil and on the Ability to Develope Mycelium of the Sclerotia of two Sclerotinia-species. In print.

(7) Frandsen, E. 1946. Studier over Sclerotinia trifoliorum Eriksson. 222 s. København.

(8) Henson, L. \& Valleau, W. D. 1940. The production of apothecia of Sclerotinia sclerotionum and S. trifoliorum in culture. Phytopath. 30: 869-873.

(9) Hino, I. 1930. Notes on sclerotia of the causal organism of Milk Vetch rot. Bull. Miyazaki Coll. Agr. a. Forestry 1930: 93-112.

(10) Justham, M. \& Ogilvie, L. 1950. Clover rot investigations. Ann. Appl. Biol. 37, 2: 328.

(11) Loveless, A. R. 1951. Observations on the biology of clover rot. Ann. Appl. Biol. 38: $642-664$.

(12) Makkonen, R. \& Pohjakallio, O. 1960. On the Parasites Attacking the Sclerotia of Some Fungi Pathogenic to Higher Plants and on the Resistance of These Sclerotia to Their Parasites. Acta agr. scand. 10, 2-3: 106-126.

(13) Mudra, A. 1958. Statistische Methoden für Landwirtschaftliche Versuche. 336 s. Hamburg. 
(14) Nicolaisen, W., Leitzke, B. \& Witzig, I. 1940. Untersuchungen im Rahmen der Züchtung der Kleearten auf Widerstandsfähigkeit gegen den Kleekrebs (Sclerotinia trifoliorum Erikss.) Phytopath. Z. 12: 585-645.

(15) Nilsson-Leissner, G. \& Sylven, N. 1929. Studier over Klöverrötan (Sclerotinia trifoliorum). Sver. Utsädesför. Tidskr. 39: 130-158.

(16) PAPE, H. 1937. Beiträge zur Biologie und Bekämpfung des Kleekrebses (Sclerotinia trifoliorum Erikss.). Arb. Biol. Reichsanst. 22, 2: 159-247.

(17) Ронјакаllio, O. 1939. Kasvinjalostusbiologisia tutkimuksia apilamädästä. S. tiedeak. esit. ja pöytäk. 1939, $115-128$.

(18) - - 1957. Untersuchungen über Antagonisten der Erreger von Pflanzenkrankheiten. Sond.abdr. Verh. IV Intern. Pfl.schutz-Kongr. Hamburg 1957, 2 (Braunschweig 1960) $1541-1543$.

(19) Rенм, E. 1872. Entwicklungsgeschichte eines die Kleearten zerstörenden Pilzes. J. Landw. Göttingen 20: 151-176 (ref. PAPE, H. 1937).

(20) RøED, H. 1954. Mitrula sclerotiorum Rostr. and its Relation to Sclerotinia trifoliorum Erikss. Acta agr. scand. 4, 1: 78-84.

(21) RUDORF, W. 1937. Untersuchungen zur Züchtung von kleekrebsresistenten Kleearten und Luzerne. Zücht. 9, 10: 249-253.

(22) Triebe, H. T. 1957. On the parasitism of Sclerotinia trifoliorum by Coniothyrium minitans. The British Mycological Society Trans. 40: 489-499.

(23) Valleau, W. D., Fergus, E. N. \& Henson, L. 1933. Resistance of red clovers to Sclerotinia trifoliorum Eriksson and infection studies. Kentucky Agr. Exp. Stat. Bull. 341: 115-131 (ref. Frandsen, K. J. 1946).

(24) Wolf, F. A. \& Cromwell, R. O. 1919. Clover stem rot. N. Carolina Agr. Exp. St. Techn. Bull. 16 (ref. PAPE, H. 1937).

\title{
SELOSTUS:
}

SCLEROTINIA TRIFOLIORUM ERIKSS. -SKLEROOTIOIDEN SÄILYMINEN MAASSA JA APILAMÅD $\AA$ N ESIINTYMINEN ERI VUOSINA

\author{
AnNa-MaRJa Halkilahti
}

Helsingin yliopiston kasvipatologian laitos

Vuosina 1954-1961 Viikin opetus- ja koetilalla suoritetuissa kokeissa osa peltomaan pinnalle asetetuista Sclerotinia trifoliorum-sklerootioista tuhoutui jo ensimmäisenä kesänä, mutta muutamia niistä säilyi elossa yli 4 vuoden ajan. Sklerootioiden tuhoutuminen oli riippuvainen kesäkauden sääsuhteista. Kuivina kesinä ne säilyivăt verraten hyvin. Sateisina kesinä ne säilyivät sitä paremmin mitä alhaisempi lämpötila oli. Kun kesä oli kostea ja lämmin, tuhoutui sklerootioita kaikkein eniten. Sklerootioiden säilyminen huononi niiden iän kasvaessa. Niitä tuhosivat mm. maasienet, bakteerit ja etanat.

$S$. trifoliorum-sklerootioista välittömästi kasvanut rihmasto saastutti apilaa. Apilamätää esiintyi myös vuosina, joina sienen apoteekioita ei löytynyt lainkaan. Taudin esiintyminen Viikissä vuosina 1954-1961 oli kuitenkin ensisijaisesti riippuvainen syksyn sääsuhteista, lähinnä sademäärästä ja syksyn pituudesta. 